- Monogràfic -

\title{
CITES AND THE BERN CONVENTION IN THE UK: AN EXPLORATION OF NORMS AND AMBIGUITIES
}

\author{
TANYA WYATT \\ Professor of Criminology \\ Northumbria University \\ (United Kingdom) \\ tanya.wyatt@northumbria.ac.uk
}

Date of Reception: April 15 2021 / Date of Acceptance: May $18^{\text {th }} 2021$

\begin{abstract}
In the Anthropocene, humans are changing and harming the planet in significant and possibly irreversible ways. Biodiversity loss is one of the main elements of these human-caused harms. Wildlife and conservation policies, such as the Convention on International Trade in Endangered Species of Wild Fauna and Flora (CITES) and the Convention on the Conservation of European Wildlife and Natural Habitats (the Bern Convention) are attempts to stop the loss of wildlife albeit in different ways (i.e., control of trade versus habitat protection). This article explores the implementation of both of these conventions in the UK through a mixed-methods study including content analysis of convention documentation and eight semi-structured interviews. The findings indicate that whilst the UK has a reputation for actively engaging in wildlife conservation and being a nation of animal lovers, management of its own wildlife is under resourced and could be improved. Both conventions are complex, with different parties focusing on different aspects. Stakeholders need to engage in dialogue about the core ethical issues regarding trade and consumption. Trying to expect the inclusion of or to add on species justice and welfare to the existing structures appears to be a step too far for the stakeholders as well as the legislative structures.
\end{abstract}


RESUM: A l'Antropocè, els éssers humans estan canviant i danyant el planeta de manera significativa i possiblement irreversible. La pèrdua de biodiversitat és un dels principals elements d'aquests danys antropogènics. Les polítiques de conservació de la fauna i flora silvestres, com ara el Conveni de Berna relatiu a la conservació de la vida silvestre i del medi natural a Europa o la Convenció sobre el Comerç Internacional d'Espècies Amenaçades de Flora i Fauna Silvestres (CITES), són intents de frenar la pèrdua de la vida silvestre. Aquest article explora l'aplicació d'aquestes dues eines al Regne Unit mitjançant un estudi de mètodes mixtos que inclou l'anàlisi de contingut de la documentació i vuit entrevistes semiestructurades. Els resultats indiquen que, si bé el Regne Unit té fama de participar activament en la conservació de la fauna i de ser una nació amant dels animals, la gestió de la seva pròpia vida silvestre manca de recursos i podria millorar-se. Tots dos convenis són complexos, ja que les diferents parts se centren en aspectes diferents (a saber, els interessos comercials a través de les narratives d'ús sostenible o la protecció de la vida silvestre mitjançant els esments al valor intrínsec). Les parts interessades han d'entaular un diàleg sobre les qüestions ètiques fonamentals relacionades amb el comerç i el consum. Pretendre incloure o afegir la justícia i el benestar de les espècies a les estructures existents sembla ser un pas massa gran per a les parts interessades i les estructures legislatives.

RESUMEN: En el Antropoceno, los seres humanos están cambiando y dañando el planeta de forma significativa y posiblemente irreversible. La pérdida de la biodiversidad es uno de los principales daños causados por el hombre. Las políticas de conservación de la fauna y la flora silvestres, como la Convención sobre el Comercio Internacional de Especies Amenazadas de Fauna y Flora Silvestres (CITES) y el Convenio sobre la Conservación de la Vida Silvestre y los Hábitats Naturales en Europa (Convenio de Berna), son intentos de frenar la pérdida de fauna y flora silvestres, aunque de forma diferente (es decir, control del comercio frente a protección del hábitat). Este artículo explora la aplicación de ambos convenios en el Reino Unido mediante una metodología mixta que incluye el análisis de contenido de la documentación del convenio y ocho entrevistas semiestructuradas. Los resultados indican que, aunque el Reino Unido tiene fama de participar activamente en la conservación de la fauna y de ser una nación amante de los animales, la gestión de su propia fauna está infradotada y podría mejorarse. Ambas convenciones son complejas, y las distintas partes se centran en aspectos diferentes. Las partes 
interesadas deben entablar un diálogo sobre las cuestiones éticas fundamentales relativas al comercio y el consumo. Pretender incluir o añadir la justicia y el bienestar de las especies a las estructuras existentes parece un paso demasiado grande para las partes interesadas y las estructuras legislativas.

KEY WORDS: species justice - wildlife trafficking - green criminology - speciesism animal welfare

PARAULES CLAU: justícia de les especies - tràfic d'animals salvatges - criminologia verda - especisme - benestar animal

PALABRAS CLAVE: justicia de las especies - tráfico de animales salvajes criminología verde, especismo, bienestar animal

TABLE OF CONTENTS: I. Introduction. II. Background of CITES and the Bern Convention in the UK. III: Methods. IV. Findings. V. Discussion and Conclusion. VI. References

\section{INTRODUCTION}

As one million species face extinction due in part to overexploitation and illegal trade ${ }^{1}$, debates are ongoing about wildlife conservation policies and practices. Crutzen ${ }^{2}$ proposed the current geological epoch should be called the 'Anthropocene' because of the noticeable, significant, and damaging effects humans were/are having on the planet. Biodiversity loss and the related wildlife conservation policies and practices sit within this context of global scale human-caused harm. This article details the findings of part of a larger study (Criminal justice, wildlife conservation and animal rights in the Anthropocene-CRIMEANTHROP ${ }^{3}$ ) that aimed to contribute to the scholarship informing debates concerning wildlife management and protection. In particular, this article documents the implementation of the Convention on International Trade in Endangered Species of Wild Fauna and Flora (CITES) and the Convention on the

\footnotetext{
1 IPBES 2019

${ }^{2}$ Crutzen 2002

${ }^{3}$ See https://www.jus.uio.no/ikrs/english/research/projects/crimeanthrop/ for more detail of this Norwegian Research Council funded project led by Professor Ragnhild Sollund at the University of Oslo.
} 
Conservation of European Wildlife and Natural Habitats (the Bern Convention) in the United Kingdom (UK).

The overall aim of CRIMEANTHROP was to explore: how is wildife conservation regulated, defended, and enforced? What are the normative and socio-legal messages this enforcement conveys? What are the implications of these messages for potential offenders, wildlife conservation, and individual animal welfare? The investigation unpacks whether species justice (both at the individual and systemic level) and ecological justice (at the level of biodiversity ${ }^{4}$ ) can be achieved by adapting these two existing Conventions or whether justice can only be achieved when individual non-human animals are granted rights ${ }^{5}$. In order to address these aims, the study explored how CITES and the Bern Convention are transposed into national politics, not only in a legal sense, but also in terms of the narratives around the Conventions. Since states transpose the Conventions into their national contexts, this means the implementation and expression of wildlife management varies. There are, therefore, differences in approaches to the integration of individual and species protection and justice in states' conservation efforts.

CRIMEANTHROP is situated within the ground-breaking, interdisciplinary field of green criminology. Green criminology sits at the nexus of social and natural sciences and is guided by a range of philosophical approaches necessary to assess humancaused harms on the environment and other species, rather than focussing only on acts that are defined legally as crimes ${ }^{6}$. These philosophical approaches range from anthropocentrism (where humans are the centre of consideration) to eco-centrism (where balance between humans and nature is advocated for) and to bio-centrism (where nature is the centre of consideration) ${ }^{7}$. In particular, this research explores speciesism-perhaps, a core aspect of the Anthropocene. Richard Ryder ${ }^{8}$ is the first person to use the word 'speciesism' in his attempt to challenge humans' unjust treatment of non-human animals. He wrote "[i]f it is accepted as morally wrong to deliberately inflict suffering upon innocent human creatures, then it is only logical to

\footnotetext{
${ }^{4}$ White 2013

5 Nussbaum 2006; Sollund 2013

${ }^{6}$ see e.g., Beirne 1999; Beirne and South 2007; Benton 1998; Halsey and White 1998; Sollund 2011, 2013, 2019; White 2013; Wyatt 2021b.

7 see White 2013 among others

8 Ryder 1971
} 
also regard it as wrong to inflict suffering on innocent individuals of other species" ". Speciesism as a concept became more widely known from Peter Singer's ${ }^{10}$ Animal Liberation where he defined speciesism as "a prejudice or attitude of bias in favor of the interests of members of one's own species and against those of members of other species". Later conceptualisations expand speciesism to not only be the unjust actions by humans towards all non-human animals, but also unpack the gradations of justice between different non-human animals, such as the better (although still exploitative) consideration for mammals over other species ${ }^{11}$ or the overexploitation of particular species because of their economic value ${ }^{12}$.

In this study, speciesism is the analytical tool used to explore part of the human-wildlife relationship ${ }^{13}$, to what extent wildlife should be managed ${ }^{14}$, and how protection is species dependent. This links closely with exploration of non-human animal rights and species justice, which are concepts that identify environmental harm in relation to the place of nonhuman animals within environments and their intrinsic right to not suffer abuse. As mentioned, per White's theorising, this is both on an individual level, but also systemically and in relation to ecological justice; the latter of which places humans as merely one component of complex ecosystems that also have intrinsic value ${ }^{15}$.

This article starts by detailing how the UK has transposed CITES and the Bern Convention into the national context. This is followed by a description of the methodology used to explore speciesism, and species and ecological justice in this context. The findings are then presented followed by a separate discussion and conclusion.

\section{Background of CITES and the Bern Convention in the UK}

The transposition of international conventions is always complex, but perhaps even more so in the UK, where there are four separate countries (England, Northern Ireland, Scotland and Wales), three crown dependencies (Guernsey, Jersey and the Isle of

\footnotetext{
${ }^{9}$ Ryder 1971: 81

10 2015/1975: 35

11 i.e., Herzog 2010; Joy 2010; Wyatt 2016, 2021b

12 Hutchinson et al Under review

13 Nibert 2002; Regan 2010; Singer 2015/1975

${ }^{14}$ Sollund 2017b, 2020

${ }^{15}$ White 2013
} 
Man) and 14 overseas territories (Anguilla, Bermuda, British Antarctic Territory, British Indian Ocean Territory, British Virgin Islands, Cayman Islands, Falkland Islands, Gibraltar, Montserrat, Pitcairn Islands, Saint Helena (with Ascension and Tristan de Cunha), South Georgia and the South Sandwich Islands, Sovereign Base Areas of Akrotiri and Dhekalia, and Turks and Caicos). An additional layer of complexity historically stemmed from the UK's membership in the European Union (EU). The EU governs overarching implementation of some wildlife conservation measures that the UK also had to implement. At the time of writing, the UK's attempt to untangle their legislation and regulation governing wildlife (and many other issues) upon exit from the EU has not been finalised with new Agriculture and Environment Bills still working their way through Parliament. In general, this is how the two Conventions are approached.

\section{CITES}

CITES aims to ensure that international wildlife trade does not threaten the survival of the species traded. The UK was the $29^{\text {th }}$ party to CITES, ratifying the Convention in August of 1976 and having it enter into force in October of the same year ${ }^{16}$. Although CITES membership is voluntary, like all international treaties, once parties have become signatories, they are required to transpose the elements of the Convention into their national legislation ${ }^{17}$. The EU became a party to CITES in 2015, which adds an additional layer to implementation for EU countries as they have to implement both EU directives and international conventions into their national legislation. For the UK, in particular England, Scotland, and Wales, both EU and CITES implementation has largely been achieved through the Wildlife and Countryside Act 1981 (WCA) and the Control of Trade in Endangered Species 2018 (COTES) (not Scotland). As mentioned, with the UK's departure from the EU in early 2021, legislation in general, but for the environment and wildlife in particular, are in flux or pending amendments. Thus, the information given here is likely to change.

CITES requires parties to have a designated Management Authority to issue permits and a Scientific Authority to provide the needed information about species' status and

\footnotetext{
${ }^{16}$ CITES no date. The overseas territories are not included in this ratification and have joined CITES individually. They are not included in the discussion.

${ }^{17}$ A detailed discussion of the distinction between types of international treaties and the differences between soft, non-binding, and hard law are beyond the scope of this article.
} 
so forth to inform the number of permits and potentially for the listing of further species. In the UK, the Management Authority is the Department of Environment, Food and Rural Affairs (DEFRA). The UK has three Scientific Authorities: the Animal and Plant Health Agency, the Joint Nature Conservation Committee, and the Royal Botanic Gardens at Kew. Although not required by CITES, the UK also has three Enforcement Authorities to ensure individuals and organisations are complying with the Convention and look for violations. These are a CITES Enforcement Liaison Team at the Animal and Plant Health Agency, the National Wildlife Crime Unit, and Border Force (which has a designated CITES team).

All of these actors work together to implement and enforce both the Wildlife and Countryside Act 1981 and the Control of Trade in Endangered Species Regulations 2018 (as well as their equivalents in other parts of the UK). WCA not only mentions trade of certain species is regulated through the 'relevant regulations' of Council Regulation 338/97/EC on the protection of species of wild fauna and flora by regulating trade, but also covers domestic exploitation and protection of wildlife in England, Scotland, and Wales. COTES also adheres to 338/97/EC and sets out the offences, penalties, and sanctions for violations. Between the two pieces of legislation then, the core requirements of CITES are fulfilled, which in addition to the Management and Scientific Authorities are: the prohibition of violations of the Convention, penalisation of violations, and confiscation of illegally traded or possessed species listed in the CITES Appendices. CITES lists over 38,000 species in its Appendices. Whilst very few of them are native to the UK, the UK does have significant volumes of trade in CITES-listed species as it is a transport and destination country for wildlife. For instance, according to the CITES Trade Database available at their website compiled from the parties' annual reports, in one year-2018-2019-the UK had 3,176 imports of CITES-listed wildlife species. These are incidents not volumes. There were also 3,103 exports that year ${ }^{18}$. Again, these are not volumes or the number of individual wildlife; leather shipments, for example, may include hundreds of items and live shipments dozens of individuals. The UK, regardless of its own lack of biodiversity, is linked to the global market for consuming wildlife.

The Bern Convention

${ }^{18}$ The CITES trade database is available at: https://trade.cites.org/ 
The Convention on the Conservation of European Wildlife and Natural Habitats came into force in 1982 and aims to "conserve wild flora and fauna and their natural habitats, especially those species and habitats whose conservation requires the co-operation of several States, and to promote such co-operation"19. Like CITES, the Bern Convention employs a listing system with appendices outlining which species are in need of protection by the signatory nations at different levels. Appendix I are strictly protected flora species, Appendix II are strictly protected fauna species, and Appendix III are protected fauna species. Overall, there are over 500 wild plant species and more than 1,000 wild non-human animal species listed in the appendices, 379 of which are in the $\mathrm{UK}^{20}$.

\begin{tabular}{|c|c|c|c|c|}
\hline \multirow{2}{*}{ Category } & \multicolumn{4}{|c|}{ Number of Species } \\
\hline & Appendix I & Appendix II & Appendix III & Total \\
\hline \begin{tabular}{|l} 
Amphibian \\
\end{tabular} & 0 & 3 & 8 & 11 \\
\hline Invertebrate & 0 & 8 & 6 & 14 \\
\hline Bird & 0 & 223 & 0 & 223 \\
\hline Fish & 0 & 4 & 16 & 20 \\
\hline Mammal & 0 & 44 & 39 & 83 \\
\hline $\begin{array}{l}\text { Non-Vascular } \\
\text { Plant }\end{array}$ & 4 & 0 & 0 & 4 \\
\hline Reptile & 0 & 8 & 4 & 12 \\
\hline Vascular Plant & 12 & 0 & 0 & 12 \\
\hline Total & 16 & 290 & 73 & 379 \\
\hline
\end{tabular}

Table 1 - Flora and Fauna Species Protected under the Bern Convention in the UK ${ }^{21}$. Please note, this list does not contain species in overseas territories.

\footnotetext{
${ }^{19}$ Convention on the Conservation of European Wildlife and Natural Habitats 1979: no page

20 JNCC 2019

21 JNCC 2020
} 
Table 1 shows that birds in the UK are the most listed family of non-human animals in the Bern Convention. They are followed by mammals in terms of both strictly protected and protected non-human animals. In regard to plants, there are 16 species (4 nonvascular and 12 vascular). Although the proportion of listed species in the UK may be small comparatively, there are still a substantial number of species, who need to be protected.

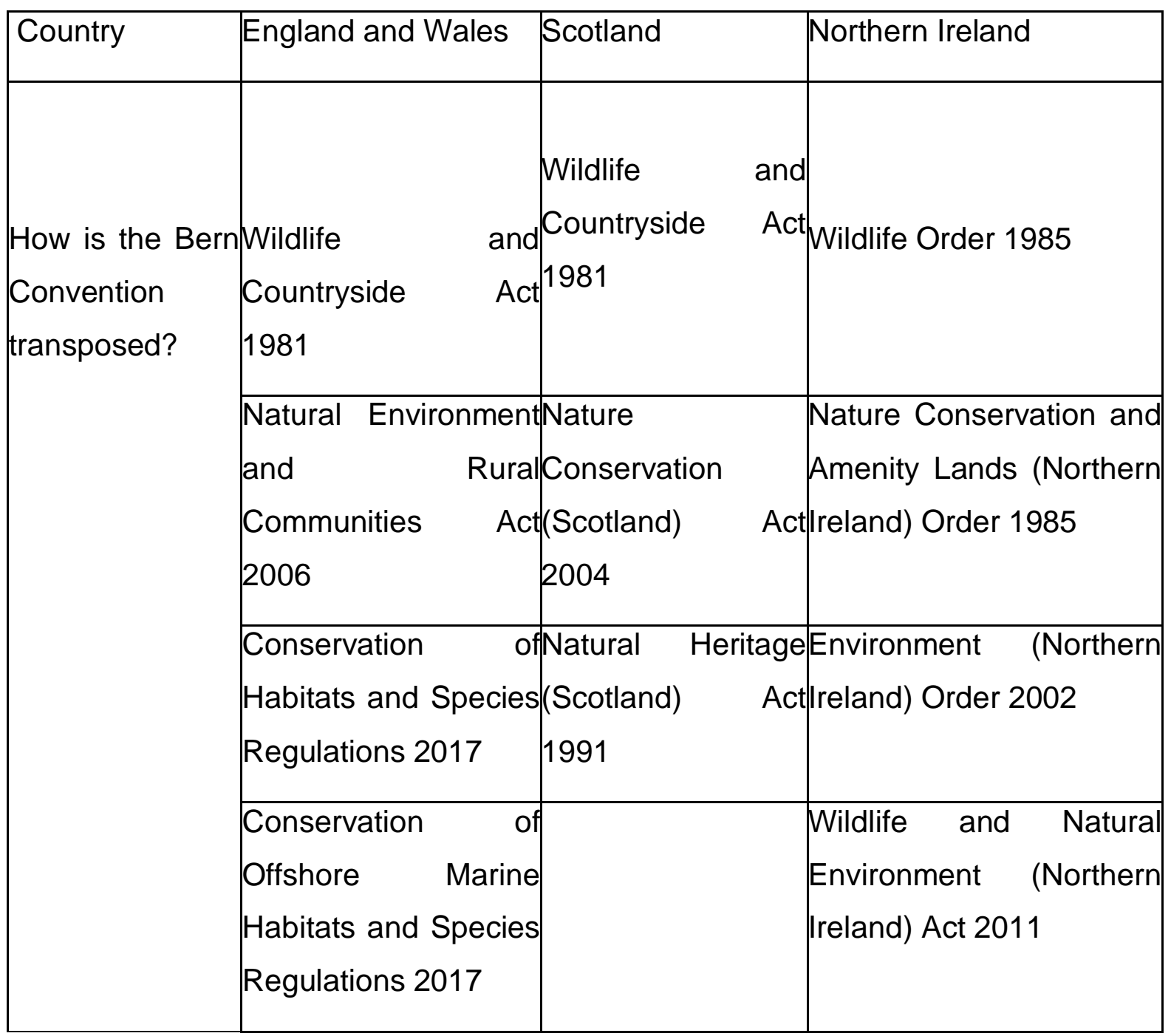

Table 2 - UK Legislation Transposing the Bern Conventions and the Relevant EU Directives

The main Act in England, Scotland and Wales implementing the Bern Convention is the same Wildlife and Countryside Act 1981 (WCA) that, in part, transposes CITES and the EU Directives. In England and Wales, the WCA criminalises 
the unlawful interference with listed species and regulates limited exploitation and use through a licensing procedure. Whilst Scotland has also adopted this statute to transpose the Bern Convention, some provisions are enacted differently. The WCA (and equivalents in other parts of the UK) employs the habitat approach to conservation through creation of Sites of Special Scientific Interest (SSSIs) to demarcate the habitats and spaces for protection. Within these areas, it is an offence to intentionally or recklessly damage or disturb the space or the species living within them. There are currently 4,124 SSSIs in England ${ }^{22}$, over 1,000 in Wales ${ }^{23}, 1,422$ in Scotland ${ }^{24}$ and 394 in Northern Ireland ${ }^{25}$. The Law Commission ${ }^{26}$ has noted that the UK approach to wildlife conservation is a "overly complicated, frequently contradictory and unduly prescriptive". This brief summary of the Bern Convention (and CITES) has not completely captured this complexity as it does not go into detail about the entirety of relevant directives and differences between countries. I will, however, attempt to highlight the conflicts as per our research questions.

Now that the legal framework is detailed, I explain the methods used to explore wildlife policies and management, whether they are speciesist, and the messages that are conveyed through the legislation's implementation and its enforcement.

\section{Methods}

The UK case study employed a mixed-methods qualitative approach. I received ethical approval through Northumbria University in August of 2019 (\#17569) and data collection took place between September 2019 and March 2020. In addition to a literature review, the methods consisted of two parts: 1) Collecting and analysing documents and 2) 8 semi-structured interviews with relevant experts. In the case of CITES, the document collection and analysis included a Freedom of Information request to the Crown Prosecution Service for court cases related to COTES and the Biennial reports from the UK government to the CITES Secretariat (seven reports

\footnotetext{
22 Natural England no date

${ }^{23}$ Natural Resources Wales no date

${ }^{24}$ Naturescot no date

${ }^{25}$ DAERA no date

${ }^{26}$ Law Commission 2015 no page
} 
available from 2003 through 2017). In regard to the Bern Convention, the document collection and analysis included the legal complaint by the Born Free Foundation, Badger Trust and Eurogroup for Animals claiming that the UK has violated the Bern Convention by culling badgers and the UK government's Biennial reports to the Bern Convention Secretariat (only 2009-2010 and 2015-2016 were available). The eight interviews (six men and two women) were experts from wildlife civil society organisations (4), law enforcement (3) and the government (1). Unfortunately, other key government experts were unavailable due to ongoing restructuring of the Department of Environment, Food and Rural Affairs in preparation for the UK leaving the EU. The identity of the interviewees is anonymous and confidential, so data from these interviews are referred to through a coding system (i.e., CS1, LE2, G1 and so forth). Interviewees were asked about both CITES and the Bern Convention. The sample was purposive based on people's expertise and experience with wildlife management in the UK. The findings of the study are set out below starting with CITES and then the Bern Convention.

\section{Findings}

\section{CITES}

As mentioned, one report required by CITES membership is the biennial report. In reality, this report is now only required every three years and since 2015 has become the Implementation report. Overall, compliance by CITES parties with the biennial/ implementation report is incredibly poor, with 67 of 183 parties never having completed them ${ }^{27}$. The UK is one of the 15 parties, which have completed all seven of them since 2003 (the time frame for when the reports are publicly available). The information in the reports provides insight into the UK government's approach to CITES implementation and into the research questions. CITES allows for parties to adopt stricter measures than the Convention text, which intimates that such party is more protective of wildlife or perhaps has found that the CITES measures are not enough. To gauge which parties take this approach, question B5 of the pre-2015 biennial reports asks: Which of the following issues are addressed by any stricter domestic

\footnotetext{
27 Wyatt 2021a
} 
measures that your country has adopted for CITES-listed species (in accordance with Article XIV of the Convention)? The UK response was:

\begin{tabular}{|c|c|c|c|c|c|c|c|c|c|c|c|c|}
\hline \multirow[b]{2}{*}{ Issues } & \multicolumn{6}{|c|}{ Conditions } & \multicolumn{6}{|c|}{ Prohibition } \\
\hline & $\begin{array}{l}200 \\
3 \\
200 \\
4\end{array}$ & $\begin{array}{l}200 \\
5 \\
200 \\
6\end{array}$ & $\begin{array}{l}200 \\
7 \\
200 \\
8\end{array}$ & $\begin{array}{l}200 \\
9 \\
201 \\
0\end{array}$ & \begin{tabular}{|l}
201 \\
1 \\
201 \\
2
\end{tabular} & $\begin{array}{l}201 \\
3 \\
201 \\
4\end{array}$ & \begin{tabular}{|l}
200 \\
3 \\
200 \\
4
\end{tabular} & $\begin{array}{l}200 \\
5 \\
200 \\
6\end{array}$ & $\begin{array}{l}200 \\
7 \\
200 \\
8\end{array}$ & $\begin{array}{l}200 \\
9 \\
201 \\
0\end{array}$ & \begin{tabular}{|l}
201 \\
1 \\
201 \\
2
\end{tabular} & $\begin{array}{l}201 \\
3 \\
201 \\
4\end{array}$ \\
\hline Trade & yes & yes & yes & yes & yes & yes & yes & yes & yes & yes & & yes \\
\hline Taking & yes & yes & yes & yes & yes & yes & yes & yes & yes & & & \\
\hline $\begin{array}{l}\text { Possessi } \\
\text { on }\end{array}$ & yes & yes & yes & yes & yes & yes & yes & yes & yes & & & \\
\hline $\begin{array}{l}\text { Transpor } \\
\mathrm{t}\end{array}$ & no & no & no & yes & yes & yes & no & no & no & & & \\
\hline Other & yes & yes & yes & & & & yes & yes & yes & & & \\
\hline
\end{tabular}

Table 4 - UK responses by biennial report year to whether they have stricter domestic measures for conditions and prohibition of certain CITES issues. Blanks indicate that there was no answer. The original form has tick boxes of yes, no, no information.

The 'other' issues box of the report form provides an open text box for more detail of any stricter measures that might be in place. In the UK context, this means "The taking and sale of some native species is also strictly regulated under licence" (2003-2004 and 2005-2006 reports). It also means that "certain bird species have to be registered with the Department" [presumably the Department of Environment, Food and Rural Affairs] (2003-2004 and 2005-2006 reports). The 2007-2008 report also notes that the UK (i.e., England, Scotland, and Wales) "Wildlife and Countryside Act 1981 makes it illegal to trade in certain species including all cetaceans". Furthermore, the European Habitats Regulations "make it an offence to, sell or exchange, or offer for sale or exchange any live or dead cetacean, or any part of or anything derived from one". I 
cannot speculate as to the changes seen on stricter measures being implemented for transportation in 2009.

As a former member of the EU, the UK had transposed EU legislation into UK legislation, which is stricter than CITES. In relation to CITES, this means Council regulation $\mathrm{EC} 338 / 97$ on the protection of species of wild fauna and flora by regulating trade therein "under which the UK bans any commercial use of raw rhino horns and EU Regulation 865/2006 laying down detailed rules concerning the implementation of Council Regulation (EC) No 338/97, which addresses pre-1947 'worked' rhino horn artefacts (2009-2010). The stricter measures seem to cover cetaceans, basking sharks, rhino horn, the re-exporting of ivory, tigers, and bear bile, paws and gall bladders. The equivalent legislation in Northern Ireland and the Isle of Man also enacts these stricter measures (2013-2014); no mention is made about Guernsey, but Jersey's legislation is also provided as is the legislation of two of the overseas territories. This was to document progress towards achieving improved implementation of CITES. As noted, the overseas territories are independent parties to CITES with the UK assisting them to fully implement the Convention.

The biennial reports also gauge enforcement of the Convention. Parties are asked whether "any of the following compliance monitoring operations [have] been undertaken?" The operations are: review of reports and other information provided by traders and producers, inspections of traders, producers, markets, Border controls, and other. For all six reports, for the first three choices the UK always answered 'yes'. In regard to 'other', twice the answer was 'no', the other four reports had no answer or no information. Parties are asked to provide information if they have imposed any administrative measures (e.g., fines, bans, suspensions), if they had any significant seizures, confiscations, and forfeitures, and if there were any criminal prosecutions. Apart from 2007-2008 in terms of administrative measures and 2003-2004 for criminal prosecutions, the answer was 'yes'. No further detail of these activities are provided in the reports.

Parties are also asked "Have there been any other court actions of CITES-related violations?" In 2009-2010 and 2013-2014, the UK answered 'yes'. No detail was provided for 2013-2014, but in 2009-2010, four zoos were visited and three of the four did not have or had the incorrect paperwork for CITES-listed species. "As there were no welfare issues at any of the zoos the specimens were not seized but the zoo's were 
warned to ensure they had the correct paperwork and that any further contraventions could lead to action being taken" (emphasis mine).

Some of the administrative measures imposed were cautions, an order to prevent the trading of Appendix 1 listed CITES species for three years, and financial penalties. Seizures included 220 live Caiman Crocodilius and 102 live seahorses (2005-2006). In general, hundreds of seizures are made each year and the biennial reports provide overall numbers and some detail on particular incidents. Even though the seizure figures appear substantial, the number of cases going to court is much less as seen in Table 6. This appears to be due to a combination of the severity of the offences (lesser violations are given cautions and so forth as mentioned) and the discretion of the Crown Prosecution Service on whether to initiate court proceedings. Seizures inevitably include live non-human animals as the companion animal portion of the wildlife trade is substantial as is the trade for zoos, science, and research. Parties are asked "How were the confiscated specimens generally disposed of?" (emphasis mine). The UK responded:

\begin{tabular}{|c|c|c|c|c|c|c|}
\hline \multirow[b]{2}{*}{ Disposal Method } & \multicolumn{6}{|l|}{ Year } \\
\hline & $\begin{array}{l}2003- \\
2004\end{array}$ & $\begin{array}{l}2005- \\
2006\end{array}$ & $\begin{array}{l}2007- \\
2008\end{array}$ & $\begin{array}{l}2009- \\
2010\end{array}$ & $\begin{array}{l}2011- \\
2012\end{array}$ & $\begin{array}{l}2013- \\
2014\end{array}$ \\
\hline $\begin{array}{l}\text { Return to country } \\
\text { of export }\end{array}$ & & & & & & yes \\
\hline $\begin{array}{l}\text { Public zoos or } \\
\text { botanical gardens }\end{array}$ & yes & yes & yes & yes & yes & yes \\
\hline $\begin{array}{l}\text { Designated } \\
\text { rescue centres }\end{array}$ & yes & yes & & yes & yes & yes \\
\hline $\begin{array}{l}\text { Approved, private } \\
\text { facilities }\end{array}$ & & yes & yes & yes & yes & yes \\
\hline Euthanasia & & & & & yes & yes \\
\hline Other & & & & & & \\
\hline
\end{tabular}


Table 5 - UK responses by biennial report year to what has happened to live confiscated wildlife. Blanks indicate that there was no answer. The original form has tick boxes of yes, no, no information.

Regarding the two reports with euthanasia being used, only the 2011-2012 report provides more information indicating invasive species (red eared terrapins) were euthanised. It is not possible to speculate if euthanasia will continue to be used in these instances. CITES recommends for repatriation, if possible, but does give discretion to the party to determine the 'disposal' of the wildlife, including euthanasia. Parties may opt for this because of fears of disease transmission (see Sollund 2019). That the UK consistently engages in CITES enforcement is supported by the statistics shared with me by the Crown Prosecution Service following my Freedom of Information request. No further information about these cases could be obtained as it was deemed too costly for the Crown Prosecution Service to provide the information for each specific case.

\begin{tabular}{|c|c|c|c|c|c|c|c|c|c|c|}
\hline \multirow[b]{2}{*}{ Statute } & \multicolumn{10}{|c|}{ Year } \\
\hline & $\begin{array}{l}201 \\
0\end{array}$ & $\begin{array}{l}201 \\
1\end{array}$ & $\begin{array}{l}201 \\
2\end{array}$ & $\begin{array}{l}201 \\
3\end{array}$ & $\begin{array}{l}201 \\
4\end{array}$ & \begin{tabular}{|l|}
201 \\
5
\end{tabular} & $\begin{array}{l}201 \\
6\end{array}$ & $\begin{array}{l}201 \\
7\end{array}$ & $\begin{array}{l}201 \\
8\end{array}$ & $\begin{array}{l}201 \\
9\end{array}$ \\
\hline $\begin{array}{l}\text { Control of } \\
\text { Trade in } \\
\text { Endangered } \\
\text { Species } \\
\text { (Enforcement) } \\
\text { Regulations } \\
1997\end{array}$ & 70 & 37 & 55 & 49 & 53 & 24 & 63 & 16 & 18 & 43 \\
\hline $\begin{array}{l}\text { Control of } \\
\text { Trade in } \\
\text { Endangered } \\
\text { Species }\end{array}$ & 0 & 0 & 0 & 0 & 0 & 0 & 0 & 0 & 0 & 14 \\
\hline
\end{tabular}




\begin{tabular}{|l|l|l|l|l|l|l|l|l|l|l|}
\hline $\begin{array}{l}\text { Regulations } \\
2018\end{array}$ & & & & & & & & & & \\
\hline
\end{tabular}

Table 6 - Offences charged and reaching a first hearing at Magistrate's Court in the $\mathrm{UK}^{28}$

A final section of the pre-2015 biennial reports that is relevant to this study is what research has been initiated by the Management and Scientific Authorities. In regard to the Management Authority, they have undertaken studies related to Basking Shark populations and genetics and identifying plant alternatives for use in Traditional Chinese Medicine (to replace Asiatic black bears, tigers and rhino horn) (2003-2004); in 2005-2006, studies included assessing the illegal trade and its impact on human livelihoods of the wild bird trade; developing genetic techniques for the forensic identification of CITES-listed timber and wood products (this was the only research continued in 2007-2008); conducting a survey of the occurrence and relative abundance of raptors in Guinea subject to international trade; starting a pilot project to use DNA to identify the species of Bushmeat being illegally imported into the UK; and reviewing the trade in plants for specialist growers, from China to the UK. Additional research in 2009-2010 was the "specific validation of DNA results using blood and mouth swabs from some of the more common birds of prey and outline work on identifying the stable isotope research into tracking movements of animals". No studies were undertaken in 2013-2014, but in 2011-2012, the UK Management Authority supported the Ivory Action Plan verification mission and the Rhino technical mission as well as supporting MIKE (Monitoring Illegal Killing of Elephants CITES programme) (in Asia) and the African elephant and rhino IUCN Specialist Groups.

The Scientific Authorities' research was conducted in these categories: populations, distribution, offtake (harvest), legal trade, illegal trade and other. The 'other' in the UK context involved creating checklists and training manuals. Table 7 shows the species that were the focus of the research undertaken or supported by the UK.

\footnotetext{
${ }^{28}$ In 2019, there is an overlap of statutes as cases charged under previous regulations work their way through the court system.
} 


\begin{tabular}{|c|c|c|c|c|c|}
\hline \multicolumn{6}{|l|}{ Year } \\
\hline 2003-2004 & $\begin{array}{l}2005- \\
2006\end{array}$ & $2007-2008$ & $2009-2010$ & 2011-2012 & $\begin{array}{l}2013- \\
2014\end{array}$ \\
\hline Herpetofauna & \multirow{2}{*}{$\begin{array}{l}\text { Aves } \\
\text { (diurnal } \\
\text { raptors) }\end{array}$} & \multirow{2}{*}{$\begin{array}{l}\text { Aves } \\
\text { (diurnal } \\
\text { raptors) }\end{array}$} & \multirow{3}{*}{$\begin{array}{l}\text { Fish and } \\
\text { aquatic } \\
\text { organisms }\end{array}$} & \multirow{2}{*}{$\begin{array}{l}\text { Madagascan } \\
\text { succulents }\end{array}$} & Sharks \\
\hline Aves & & & & & \\
\hline Mammalia & \multirow{5}{*}{$\begin{array}{l}\text { Species } \\
\text { collected } \\
\text { by Alpine } \\
\text { plant } \\
\text { specialists } \\
\text { in the UK }\end{array}$} & Corals & & \multirow{2}{*}{$\begin{array}{l}\text { Fish and risk of } \\
\text { overexploitation }\end{array}$} & \\
\hline Invertebrates & & Testudinidae & Testudinidae & & \\
\hline Swietenia & & & \multirow{2}{*}{$\begin{array}{l}\text { Galanthus } \\
\text { and } \\
\text { Cyclamen }\end{array}$} & Sharks & \\
\hline Gonystylus & & & & \multirow[t]{2}{*}{$\begin{array}{l}\text { Live wild bird } \\
\text { imports to EU }\end{array}$} & \\
\hline Orchids & & & Nomenclature & & \\
\hline $\begin{array}{l}\text { Succulent } \\
\text { plants }\end{array}$ & Ramin & & $\begin{array}{l}\text { Ramin and } \\
\text { timber }\end{array}$ & $\begin{array}{l}\text { Falcon captive } \\
\text { breeding }\end{array}$ & \\
\hline CITES plants & & & Cacti & $\begin{array}{l}\text { Tortoise } \\
\text { marking }\end{array}$ & \\
\hline
\end{tabular}

Table 7 - Summary of the Focus of Research by the UK CITES Scientific Authorities

As mentioned, the biennial report changed in 2015 to be an Implementation report, so the questions and format were completely changed. Overall, the UK reports that they have full implementation of CITES's various elements. Of interest to this study are the questions related to demand reduction and improvements in species' populations as these document the UK's approach to wildlife management as well as whether it is working. In regard to demand reduction, the efforts outlined are all in other parts of the world. The UK's Illegal Wildlife Trade Challenge Fund, which supports projects to reduce illegal wildlife trade, only funds projects in countries with lower incomes. In terms of species' populations, the question is: "Do you have data which shows that the conservation status of naturally occurring species in your country listed on the CITES Appendices has stabilized or improved?" For all three appendices, the answer was 'yes'. With further detail saying: 
"Although a number of status surveys have been undertaken, and are ongoing, on UK wild native Appendix I and Appendix II species (such as peregrine falcon) because the UK does not normally export wild-taken specimens of native fauna the details of these surveys have not been attached to this report. Full details can be provided upon request. The status of Scottish Wild Cat (Felis silvestris) is constantly monitored by Scottish Natural Heritage. UK native birds of prey (F.peregrinus (App I) and UK native birds of prey and owls are regularly monitored through a number of partnership schemes including periodic national targeted surveys, annual reporting, where relevant, by the Rare Birds Breeding Panel (http://www.rbbp.org.uk/), through the Breeding Bird Survey (https://www.bto.org/volunteer-surveys/bbs), and by other volunteer schemes (e.g. see http://raptormonitoring.org/ and http://www.scottishraptorstudygroup.org/). With regards to CITES listed Cetacea, here is an obligation under Article 11 of the Habitats Directive to undertake surveillance on the conservation status of all cetacean species occurring in UK waters and report on this every six years. Monitoring is undertaken between decadal surveys".

The above provides information upon which a discussion (see later section) regarding speciesism can in part be grounded. For the other elements of this study, the findings from the interviews are needed. In regard to CITES, the interviews contained four themes - interpretation, effectiveness, normative consumption, and lack of welfare.

\section{$\underline{\text { Interpretation }}$}

Of the eight interviews, no one agreed or felt that CITES was ambiguous. Instead, participants argued stakeholders focus on different elements.

“it [CITES] sort of evolves much more with time. I suppose... I wouldn't say it's ambiguous however, different readers of the text focus on different aspects. So, colleagues in... I don't wanna pick on anyone, but in South Africa would focus on some of the words, or rather the concepts around sustainability and sovereignty whereas others may focus on some of the bits around the sort of conservation and that sort of thing, that side of it" (CS4).

In terms of sustainability, another participant felt this is where change has happened.

"I think what has changed is the use of the phrase sustainable utilisation as a sustainable use, that's not exclusive to CITES by any means, but across the UN sector [and] other international agreements. It's a phrase that's bandied around and a lot of... there's a lot of assumption that it only means lethal consumptive use..., in order to justify the existence of having rhinos or elephants, they have to pay their way in their body parts [i.e., trade and trophy hunting]" (CS1).

In addition, sustainable use is applied uniformly to the $38,000+$ CITES species, but you cannot hunt and kill all of these species or approach their use in the same manner (CS2). 
With international conventions, such as CITES, where the convention text has to be transposed nationally, states interpret their international obligations in ways that are useful to them (CS3; LE1). Again, the participants did not think this stems from ambiguity. Furthermore, when linking this to enforcement, if frontline officers were not enforcing the UK national legislation, it was not thought that this happens because of ambiguity, but because the wildlife law regime is complicated, which turns law enforcement off from enforcement (G1).

The one mention of ambiguity was in relation to "not calling a crime a crime" (LE1). This participant felt it was too ambiguous and gentle to not firmly call or label wildlife trafficking as a crime. Many conservation organisations are reluctant to call the people stealing wildlife thieves or offenders, or to see poaching as a crime (LE1). This is indirectly apparent in CITES, which does not require violations to be a crime (they can be administrative or civil offences), but again CITES is a trade treaty not a penal code. This participant also noted that the reverse concern is also taking place, which is treating every crime as an organised crime, when in fact the reality is much more nuanced (LE1).

\section{Effectiveness}

In the discussions around ambiguity and the implementation and enforcement of CITES, participants shared thoughts on whether CITES was effective or whether, in essence, it was working. At the international level, it was pointed out the permit and non-detriment findings systems were open to abuse (CS4). That is because these systems rely on trust and self-certification, where parties are given governance over the regulatory structure, but some cannot or do not comply with maintaining properly validated permits and scientifically-based non-detriment findings (NDF) ${ }^{29}$ (CS4). In terms of the UK, this participant felt that the UK's application of CITES "does make a contribution to species conservation globally" (CS4). And in the local context:

"it's better than many other places I think, but it's still not especially well resourced. It has a reasonably robust scientific authority, management authority up to certain points, I mean the animal health and plants authority, not much in the way of capacity, so... although that's changing with Brexit for obvious reasons. But there's not really the capacity to check effectively

${ }^{29}$ The verification process undertaken to ensure that trade will not harm the survival of a species. 
across a whole range of the permits and things that are submitted so they can only follow up on so many things, and they are also hindered in certain cases by what I was referring to about the certain non-detriment finding and the idea of that kind of self-certification around NDF. So they [the UK] are obliged to just take what certain countries say about sustainability or otherwise with regards to NDF" (CS4).

Other participants agreed that the UK does well and that CITES was working in the UK (particularly Border Force) (G1, LE3), but indicated areas for improvement. SEPRONA in Spain was highlighted as a good model of a specialised team of prosecutors and judges (LE3). In contrast, participants felt that not enough resources were dedicated to prosecutions in the UK (CS4, G1, LE3) and that there were specific priorities for the national law enforcement that overrides wildlife crimes (and having a specialised team would address this ${ }^{30}$ ):

"the way that Border Force has to work with the National Crime Agency, because Border Force can't prosecute themselves, they have to use National Crime Agency to take their cases and they [the National Crime Agency] are very loathe to take on anything that isn't to do with child pornography or drug smuggling, basically" (G1).

When cases are prosecuted in the UK, the sentences:

"aren't exactly all they could be and I don't necessarily subscribe to the idea of deterrence through sentencing but you know they're not all they could be and yeah, I think the UK could do a bit better in regards to that sort of stuff" (CS4).

There was some concern that:

"the internet and the modern way of living has meant that things have moved on beyond CITES, and either it needs something to change its whole ethos, which is basically the ethos is to facilitate legal trade safely, and we need to be looking potentially at the health issues, the nonendangered species issues, things that don't hit that radar" (LE3).

Importantly, enforcement of wildlife crime in the UK (not the ports, which is Border Force) is at the discretion of the chief constables of the constabularies, who decide how much of their budget goes to wildlife crime (LE1). According to this participant, wildlife crime, including CITES violations, are swamped by terrorism concerns from the central UK Home Office and by more serious crime concerns from the regional organised crime initiatives. Furthermore, the National Wildlife Crime Unit is always kept wanting for resources and is in a cycle of instability over funding (LE1). This

\footnotetext{
${ }^{30} \mathrm{It}$ is worth noting that Scotland does have a specialised prosecution unit the Wildlife and Environmental Crime Unit (WECU).
} 
participant's speculation was there are political underpinnings as to why wildlife crimes are not better funded or prioritised. The worst offenders are rich landowners, who can corrupt the government decision making and who do not want law enforcement looking into wildlife crime ${ }^{31}$. Overall, though, the attitudes of the officers and chief constables would need to change to be more responsive to wildlife crime in the UK and globally (LE1).

In short, "it [CITES] does make a difference, whether in the long term it's a good difference it's difficult to say" (LE2).

\section{Normative consumption}

"A place to start discussion around wildlife trade is do we need trade in the first place?" (LE1). But CITES is a trade treaty that focuses on regulating trade, not preventing it (CS3). The Convention text, however, acknowledges more than the economic value of wildlife (anthropocentrism), but also the cultural and intrinsic value (CS3, CS4) (more eco-centric or bio-centric approaches). One participant noted though:

"I mean we maybe start moving onto the philosophical question about whether they [wildlife] should be commodified in that way but I am not a legal expert, but how else would we cater for things within the English law if it didn't have a value or if it potentially didn't have a commodity or run by someone or have some sort of status. And although I'm romantically inclined to the idea of inherent value, I'm not so concerned about commodification, and I'm actually thinking as I'm talking, to some extent some of the things in the Wildlife and Countryside Act do attribute an inherent value to wildlife, although it wouldn't be for.. There is no commodity value placed upon wild birds or species that can't be interfered with, killed etcetera, although its actually attributing an inherent value isn't it?" (CS4).

Thus, this participant disagreed CITES sets a normative message around the consumption of wildlife. They also pointed to recent CITES decisions regarding ivory and elephant populations that were not about preserving a commercial resource. There are, however, those who focus exclusively on the commercial aspects and sustainability in the Convention (CS4). In agreement with the latter, another participant stated:

\footnotetext{
${ }^{31}$ In the UK context, this is not CITES related, but linked to illegal fox hunting and raptor persecution on the moorlands where canned hunting of pheasant and grouse earn landowners considerable income (LE1).
} 
"Benefits and profits are thought to be the only way to conserve species and habitats. Every single one of the targets has been missed. Maintaining the utlilisation at the current levels is completely failing not only in CITES, but also the CMS [Convention on Migratory Species]. Sustainable development is only interpreted commercially. If we continue to use value and monetary criteria, this only focuses on certain species - it is a skewed process from the core to only manage wildlife and the environment based upon maximum return" (CS3).

Both of these participants agreed that Appendix listings on their own do not change the nature of the trade and are grounded in the assumption that listings indicate that the trade is sustainable, although it may not be (CS3, CS4).

\section{$\underline{\text { Welfare }}$}

"By promoting conservation of species and habitats, then you are going to improve the welfare of individual animals, but it is not the purpose of either convention. I think there are potentially some issues with CITES with regards to things like appropriate and acceptable destinations and the management of sea specimens and the management of captive bred specimens, but it's kind of, and I can understand why the Convention would say it, out of the scope of the Convention, but It is potentially an issue" (CS4).

In the UK context, those working directly with CITES are sensitive to welfare in trade. As one participant said to me:

"One of the things we're hot on here is ... the IATA Live Animal Regulations. We're quite heavily involved in those as well. A lot of the customs seizures in the UK have been [made] we like that, that's improved animal welfare transport quite significantly. If they're not shipped properly, they lose their consignment, so that hits them in the pocket. Because tortoises and reptiles, some of the packaging has been abominable in the past. As I say, we'll prosecute the airlines but until we started seizing them it didn't really have any effect on the importers. Rehoming is one of the things it would be nice if it was sped up, it can be a bit slow. I know rehoming of seized goods is an issue with CITES around Europe, it's what do you do with them? It does put countries off seizing them" (G1).

As other participants noted, IATA-the International Air Transport Authorityguidelines are the only real element of welfare covered by CITES (CS3, LE3). It has been effective in improving the conditions of many wildlife.

"What the end effect is that you very, very rarely see live animals, particularly CITES ones, being shipped from one country to another where their welfare's not been dealt with in accordance with IATA regulations if nothing else. So like in the old days you used to see in the press you know, if you go back to the '70s, a shipment of birds and half the birds are 
dead and escaping out of the box, you never see that because it's not in anyone's interest, it's not in the trader's interest because if it turns up at Heathrow the importer won't accept it" (LE3).

Whereas these guidelines and those for non-air transport mitigate the effects of transport for some live wildlife, there is nothing about the harvest and killing methods (CS3). Furthermore, according to one participant, the guidelines only apply to Appendix I live species, which means they are only applicable to wildlife being moved for non-commercial purposes. Thus, the larger scale movement of Appendix II species is not covered (CS3). But as they said to me, welfare does not depend on conservation status. This participant's organisation is trying to work with the CITES Secretariat to improve this.

CITES was never designed to deal with welfare or the environment (LE3) and there is not a space to discuss other ways to use wildlife besides killing them (CS1). "I don't know but maybe because it is animals and there are NGOs as well, tree hugging NGOs are involved and it's pitted as tree hugging NGOs versus communities, which is what it became I feel at the last CoP [Conference of the Parties]" (CS2).

I now move on to talk about the same issues in relation to the Bern Convention; the discussion of these findings are in a later section.

\section{The Bern Convention}

Like CITES, the Bern Convention requires biennial reporting from parties as to actions that they have taken. These reports document all the exceptions to protection of species listed in the three appendices outlined earlier. Thus, all of the licenses issued by the relevant authorities are listed for each of the four countries, the Isle of Man and Jersey (for some unknown reason Guernsey is missing). To illustrate the patterns of species for whom exceptions are granted and the reasons given for these, I highlight the trends present in the 2009-2010 biennial report. During that time frame, 23 different strictly protected plant species (Appendix I) were subjected to harvesting, all for research, education, repopulation, or reintroduction. One of these plants-Floating Water Plantain (Luronium natans) -was also harvested for other overriding public interest. In each granting of the licenses, the authority deemed this to have a negligible and/or no projected impact. This species also had the most licenses given (54) in 
comparison to other plant species, where the licenses for other plant species were usually less than ten and very frequently one or two (more than $50 \%$ ). The number of licenses issued, however, does not give an indication of the level of harvest. Whereas the number of 'specimens' harvested is requested, in over $50 \%$ of the cases no numbers are given. Furthermore, in more than $25 \%$ of the cases, no restrictions were placed on the number of plants that could be harvested.

In comparison, there are 51 strictly protected non-human animal species (Appendix II) and 52 protected non-human animal species (Appendix III) for whom licenses were issued. A majority of licensing for the strictly protected species listed is of bats (21 categories with 19 specific species and 2 general 'bats' groupings; 6,960 licenses totalling a minimum of 38,839 bats with 5 species not having their numbers recorded) and cetaceans (12 species; 47 licenses in total including an unknown number of individuals). The reasons for exceptions in licensing for bats are: the protection of flora and fauna; to prevent serious damage to crops, livestock, forests, fisheries, water; public health and for research, education, repopulation, or reintroduction. The actions that the license permitted included: deliberate killing; deliberate damage to or destruction of breeding or resting sites; deliberate capture and keeping; and deliberate disturbance of wild fauna. Even though the details of the bats licensing indicates that no bats were killed, Section 1.4 of the report "Exceptions concerning the use of means of capture and killing specified in Appendix IV" indicates that 370 bats of 17 species were euthanised under the Animal Health Act. In a vast majority of cases, cone, funnel, and harp traps as well as static hand-held and mist nets were used to catch the bats. They are then studied, tagged, and released or relocated. Roosts are destroyed by hand in several instances. In regard to the cetaceans, the reasons for the exceptions were mainly research and also in the interest of public health (presumably related to cetaceans washing up on beaches and decomposing). The actions that were permitted predominantly were deliberate damage to or destruction of breeding or resting sites, deliberate disturbance of wild fauna, and possession and internal trade. Apart from one dolphin species where five were covered in one license, the only detailed information given is that the 11 licenses for porpoises covered 602 individuals, who could also be subjected to deliberate capture and keeping other forms of property. Further information indicates that none were captured or killed. 
As mentioned, the culling of badgers in the UK has sparked controversy and a legal challenge. Badgers are listed in Appendix III of the Bern Convention, so need a recognised exception to be killed or disturbed. According to the complaint filed by the Born Free Foundation, Badger Trust and Eurogroup for Animals, 67,000 badgers have been killed between 2013 and July 2019 in England; their complaint suggests the badger deaths do not meet any of these exceptions. In 2019, the cull was set to continue despite the fact, as argued by these groups, the estimated badger population numbers are inaccurate and declining, other protected species are harmed by the cull, and that the cull is not affecting the rates of bovine tuberculosis, which is the main justification provided for the killing of the badgers (in addition to numerous other reasons to stop the culling). As of the time of writing, there is no decision on this complaint. It is noteworthy, however, that the scale of death to badgers is not apparent from the UK's Bern Convention biennial reports as no figures are included of the exact number of individual badger's lives lost.

Unlike the other case studies in the CRIMEANTHROP project, the UK has very few remaining predator species having eradicated wolves and lynx centuries ago. Foxes continue to be persecuted through hunting despite the Hunting Act 2004 (League Against Cruel Sports 2021), the Scottish Wildcat has nearly been eradicated although there are intensive efforts to save them ${ }^{32}$, and birds of prey are subjected to various forms of harm and crime. Eagles, falcons, and hawks are poisoned, shot, and snared by farmers and gamekeepers who believe the birds of prey kill their livestock and gamebirds (grouse and pheasant) and/or steal food from their gamebirds ${ }^{33}$. In addition, birds of prey are exploited for falconry. This is relevant to the Bern Convention, where falconry is a standalone exception to the protections of the Convention, thus allowing some amount of capture and trade of raptor species throughout Europe. As I have noted elsewhere (BLINDED for review) captivity and transport for birds of prey are highly stressful and there is an illegal trade partly fulfilling the demand for falconry.

Only one of the eight interviewees dealt in any substantial way with the Bern Convention. A majority had no knowledge of how it was implemented in the UK, though they had an idea of its purpose. For instance,

\footnotetext{
32 Saving Wildcats 2020

${ }^{33}$ Royal Society for the Protection of Birds 2019
} 
"Even within the UK office where I work, there are folks who work on some wider UK based conservation issues who l'd say aren't really familiar with the Bern Convention at all. So, wouldn't necessarily connect here in the UK some of the things around habitats and species within the Wildlife and Countryside Act and so on, with the Bern Convention at all" (CS4).

In the UK context (as with other EU countries), there is an additional layer that might obscure the public's and officials' knowledge of the Bern Convention. As mentioned, the Bern Convention is implemented in the EU though different directives, including the Habitats and Birds directives. Whereas people may be aware of these (or not), they do not know these implement the Bern Convention (CS4). The public and organisations may also not link the Natura 2000 sites (SSSIs) with the directives of the Bern Convention. This interviewee thought the lack of knowledge was perhaps due in part to the Bern Convention being less controversial, so has received less news media attention and public scrutiny. Another interviewee agreed that the layers of regulation are why the Bern Convention may be less well known: "obviously we don't see it in its original form, that's the point about most of these things, it's like any EU legislation, the regulations are then interpreted into UK law and, so we see it in that form" (LE3).

One interviewee suggested, however, "Are the UK government deliberately quiet about the Bern Convention because they are non-compliant?" (LE1). This is alluding to the ongoing badger cull. The cull is perhaps the main source for why the Bern Convention in the UK is not working.

"For the Bern Convention, I think that the UK is not doing exceptionally well with regards to species and habitats conservation. It has missed virtually all of the targets that it's set that are linked to the Bern Convention for the UK. There are breaches around things like its approach to badgers" (CS4).

Furthermore:

"So, I suppose if you are looking at the Bern Convention I suppose there are species like as I mentioned, the badger, and there are a few others, large carnivores and things that are, kind of, you know, exceptions are made as to how countries manage them, and its linked to, obviously in the case of badgers, linked to agricultural concerns, and similar for some of the large carnivores, so I think those are species that perhaps aren't protected as effectively and fully as they should be" (CS4).

Thus, participants were only able to share their perceptions that the Bern Convention does not seem to be working in the UK context. With little knowledge of the 
Convention, they were unable to speculate as to the normative messages or possible ambiguity; the legal complaint is the most substantial piece of evidence that the Bern Convention is ineffective in protecting wildlife. It was noted that the Bern Convention is not concerned about individual animals and/or welfare and that compliance by the parties was difficult for the European Commission to enforce (CS4). Again, the implementation of the Bern Convention, and therefore the UK compliance with it is a dynamic space; the Habitats directive will be replaced by the UK Environment and Agricultural Bills since it is EU legislation, but the UK will still be a member of the Bern Convention since it is still part of the Council of Europe, so needs to maintain legislation that implements the required provisions (CS3).

\section{Discussion and Conclusion}

According to David Attenborough: "It's tempting to assume loss of wildlife is a problem happening on the other side of the world. The truth is the UK is one of the most naturedepleted countries on the planet and the situation is getting worse" 34 . The UK biennial reports of CITES and the Bern Convention support the contention that the UK approach to wildlife conservation is to prioritise wildlife in other parts of the world. In terms of CITES, research and funding on endangered species and the illegal wildlife trade are concentrated abroad and not focused on the consumption of wildlife taking place in the UK either in terms of native or non-native wildlife or of wildlife imported or exported. Even supposedly reputable organisation like zoos have been found to be in violation of the CITES permit system. The killing of tens of thousands of a Bern-listed species in the UK is glossed over. Presumably, this is to preserve their international reputation as wildlife protectors, to shield themselves from being held accountable for violating international conventions, for which there is an ongoing legal complaint, and to protect the economic interests in conflict with wildlife conservation (i.e., agriculture and construction). The Bern documentation in particular evidences this state theriocide ${ }^{35}$ not only of badgers, who are targeted by the ongoing cull, but of bats as well through their routine destruction during human construction projects. In the UK, the harm goes beyond the death of wildlife. Wildlife are also tagged and marked for

\footnotetext{
34 The Guardian 2021

35 Sollund 2017 a - the mass killing of non-human animals by the government.
} 
identification purposes, which is known to be painful as well as to disturb their natural behaviours and life cycles ${ }^{36}$.

These reports and the other documentation analysed also reveal to some degree the speciesist approach of the Conventions and of the UK to wildlife conservation. This is in terms of humans being prioritised over other species and also of certain non-human animals being prioritised over other non-human animals. In regard to the former, wildlife are 'specimens' who are 'disposed' of. Wildlife are a resource for 'sustainable use', but some participants noted that use only happens through death. The hierarchy of speciesism between non-human animals is evident with the focus of protection on bears, tigers, elephants, and rhinos historically. That may have begun to change with more recent projects targeting the protection of tortoises and sharks. Yet, I suggest that the badger cull evidences ongoing speciesism; the badger-a wild non-human animal with apparently no material value to humans-is scapegoated for a disease within the English cattle population-a domestic non-human animal at the centre of a profitable industry. A non-human animal's worth to humans and our economic markets determine whether or not wildlife are protected and to what degree.

Whereas this study and the larger CRIMEANTHROP study sought to explore the ambiguity within CITES and the Bern Convention in specific national contexts, my participants did not agree that there was ambiguity. They, like other studies have shown ${ }^{37}$, felt countries chose to focus on certain aspects of the different Conventions that allowed them to act in their own self-interest. By and large this has led to prioritisation of commercial industries be that wildlife trade in terms of CITES or agriculture in terms of the badger cull and cattle in the UK. Such manoeuvring is perhaps inevitable and unavoidable for international conventions that are drafted and implemented by hundreds of individual stakeholders. Relatedly, most participants did not recognise that either Convention (but CITES in particular) communicates a normative message around wildlife consumption. On the contrary, one participant noted that CITES, even though it is a trade treaty, explicitly acknowledges nonspeciesist or eco-centric value of wildlife that is beyond economics. However, the concept of sustainable use was identified as being grounded in anthropocentric assumptions of 'use' being the human killing of wildlife. This was not confined to CITES

\footnotetext{
${ }^{36}$ Cazaux 2007

${ }^{37}$ Challender and MacMillan 2019; Wyatt 2021a
} 
though but thought to pervade the conservation world. Although the Conventions are effective to some degree, participants did note that most targets are not met and that resources are lacking. Not having the legislation that transposes the Conventions though was thought to likely lead to worse outcomes than the current state. Thus, whilst there is much room for improvement, both Conventions are at least to some degree thought to be working. That 'working' does not take into account non-human animal welfare, and whilst for a few participants this was potentially problematic, for the most part the interviewees argued that is not what the Conventions were meant to do nor is it necessarily feasible for the Conventions to be adapted in this regard.

There is a disconnect between the CITES and Bern Conventions and people's knowledge and perceptions of them. In the UK context, that disconnect is perhaps though not the one that was the focus of the study. The larger CRIMEANTHROP study set out to investigate the ambiguities of the Conventions as well as the normative and socio-legal messages that are conveyed from their enforcement. A majority of participants in the UK, however, did not directly engage with the Conventions (particularly the Bern Convention), so either did not have opinions about their ambiguity, their speciesist underpinnings, or their messaging. Furthermore, participants disagreed that there was ambiguity or only a normative message about consumption. The participants, who are people enforcing the Conventions or who are trying to improve the way that the Conventions are enforced, are not contemplating whether or not there are ambiguities or examining their own level of discretion to complete their duties. For the most part, they are mission driven stakeholders (conservation and law enforcement) not engaged with the philosophical debates about welfare, speciesism, and individual non-human animal rights. They are not in positions to theorise about new and radical approaches to achieving their mission (which is conservation and/or law enforcement not non-human animal welfare); they are working with the tools (the transposed national legislation from the Conventions) given to them. Whereas there was recognition that more resources are needed to achieve the aims of CITES and the Bern Conventions, for the most part, my participants did not see how intrinsic value or individual non-human animal rights could be worked into the existing frameworks, much more than they already are. As one interviewee correctly noted, conservation does, even though indirectly, protect [some] individual non-human animals. 
Overall, this study documents that in the UK context wildlife conservation has complex regulation across nations, crown dependencies, and overseas territories. This complexity leads to limited direct knowledge of the Bern Convention, whereas CITES was known to all participants. The UK is actively engaged in defending wildlife via the transposed legislation although the data show that the wildlife who are the focus of these efforts tend to be outside of the UK. This is somewhat the case in regard to enforcement as well, where there are continual efforts particularly in terms of CITES (which largely protects species outside of the UK), but fewer prosecutions and convictions. The international reputation of Border Force, such initiatives as the Illegal Wildlife Trade Challenge Fund (amongst others), and the continual enforcement efforts, including ensuring welfare in transport-although these may not be targeted at UK species-sends the message that the UK is concerned about wildlife conservation and welfare. And whilst this is to a large degree true, the implications of this approach and this message are that wildlife in the UK are overlooked, as is welfare outside of the transportation context. Importantly, the larger implication of the study is that if speciesism and individual non-human animal welfare are going to be discussed on the global agenda in regard to such conventions as CITES and Bern, then much more fundamental conversations need to be arranged to discuss core ethical issues regarding trade and consumption. Trying to expect the inclusion of or to add on species justice and welfare to the existing structures appears to be a step too far for the stakeholders as well as the legislative structures. If the lives of non-human animals are going to be improved within the Anthropocene, there is more basic dialogue that needs to be had with the range of policy makers, and criminal justice and civil society practitioners working in wildlife conservation.

\section{References}

BEIRNE, Piers. Towards a Non-Speciesist Criminology, Criminology, 1999, 37(1): 117-148.

BEIRNE, Piers. and SOUTH, Nigel. (eds). Issues in Green Criminology, Willan: Cullompton, UK, 2007.

BENTON, Ted. Rights and justice on a shared planet: More rights or new relations. Theoretical Criminology, 1998, 2(2), 149-175. 
CAZAUX, G. Labelling animals: non-speciesist criminology and techniques to identify other animals. In Beirne, P. and South, N. (eds.), Issues in Green Criminology: Confronting harms against the environment, humanity and other animals. Willan: Cullompton, 87-113.

CHALLENDER, D. and MACMILLAN, D. Investigating the Influence of Non-state Actors on Amendments to the CITES Appendices. Journal of International Wildlife Law \& Policy, 2019, 22: 2, 90-114.

CONVENTION ON THE CONSERVATION OF EUROPEAN WILDLIFE AND NATURAL HABITATS.

Bern, 1979, Article 1.

CONTROL OF TRADE IN ENDANGERED SPECIES REGULATIONS (COTES). 2018. https://www.legislation.gov.uk/uksi/2018/703/contents/made. Accessed 8 April 2021.

CONVENTION ON INTERNATIONAL TRADE IN ENDANGERED SPECIES OF WILD FAUNA AND FLORA. List of Contracting Parties. No date. https://cites.org/eng/disc/parties/chronolo.php. Accessed 8 April 2021.

CRUTZEN, P. The Anthropocene. Journal de physique. 2002, 12, 1-5.

DEPARTMENT OF AGRICULTURE, ENVIRONMENT AND RURAL AFFAIRS (DAERA). Protected Areas. No date. http://www.daera-ni.gov.uk/protectedareas/type/assi. Accessed 7 February 2021.

THE GUARDIAN. Wildlife charities raise £8m to boost nature schemes across England and Wales. 2021.

https://www.theguardian.com/environment/2021/apr/07/wildlife-charities-launch-10schemes-to-boost-nature-across-england-and-wales. Accessed 10 April 2021.

HALSEY, Mark and WHITE, Rob. Crime, ecophilosphy and environmental harm. Theoretical Criminology, 1998, 2(3), 345-371.

HERZOG, Hal. Some We Love, Some We Hate, Some We Eat. Harper Collins: New York, 2010. 
HUTCHINSON, Alison, STEPHENS-GRIFFIN, Nathan and WYATT, Tanya. CITES and Speciesism: analysis of uplisting, delisting and listing. International Criminology. Under review.

INTERGOVERNMENTAL SCIENCE-POLICY PLATFORM ON BIODIVERSITY AND ECOSYSTEM SERVICES (IPBES). IPBES Global Assessment Summary for Policymakers.

2019. https://www.ipbes.net/sites/default/files/downloads/summary_for_policymakers_ipbe s_global_assessment.pdf. Accessed 7 May 2019.

JOINT NATURE CONSERVATION COMMITTEE (JNCC). Conservation Designations for UK Taxa 2020. https://hub.jncc.gov.uk/assets/478f7160-967b-4366-acdf8941fd33850b. Accessed 28 January 2021.

Bern Convention. 2019. https://jncc.gov.uk/our-work/bern-convention/. Accessed 28 January 2021.

JOY, Melanie. Why We Love Dogs, Eat Pigs And Wear Cows: An Introduction To Carnism. Conari Press: San Francisco, CA, 2010.

LAW COMMISSION. Wildlife Law. 2015, Vol 1, 3 https://www.lawcom.gov.uk/project/wildlife-law/. Accessed 13 April 2021.

LEAGUE AGAINST CRUEL SPORTS. Fox hunting. https://www.league.org.uk/foxhunting. Accessed 13 April 2021.

MORROW, Karren. European Union Habitat Conservation Activities and Individual Property Rights: Law and the Meaning of LIFE. National Italian American Bar Association Law Journal. 2009, 17(13).

NATURAL ENGLAND. Designated Sites View. No date.

https://designatedsites.naturalengland.org.uk/ReportConditionSummary.aspx?SiteTy pe=ALL. Accessed 7 February 2021.

NATURAL RESOURCES WALES. Types of protected areas of land and sea. No date. https://naturalresources.wales/quidance-and-advice/environmental-topics/wildlifeand-biodiversity/protected-areas-of-land-and-seas/types-of-protected-areas-of-landand-sea/?lang=en. Accessed 7 February 2021. 
NATURESCOT. Sites of Special Scientific Interest. No

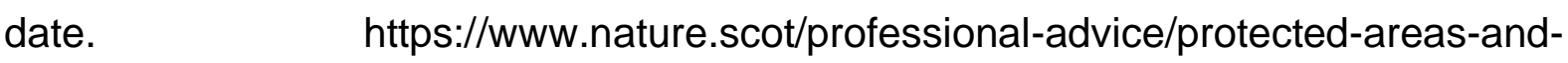
species/protected-areas/national-designations/sites-special-scientific-interest. Accessed 7 February 2021.

NIBERT, David. Animal rights, human rights. Rowman and Littlefield: Oxford, 2002. NUSSBAUM, Martha. Frontiers of justice: Disability, nationality, species membership. Harvard University Press: Boston, 2006.

POTTER, John. SSSI- Three S's but still one missing. The Environmentalist. 2001, 91-92.

REGAN, Tom. The case for animal rights. University of California Press: Berkeley, 2010.

ROYAL SOCIETY FOR THE PROTECTION ON BIRDS. Bird Crime Report 2019. https://www.rspb.org.uk/birds-and-wildlife/advice/wildlife-and-the-law/wild-birdcrime/birdcrime-report-2019/. Accessed 25 May 2021.

RYDER, Richard. Experiments on Animals. In Godlovitch, S., Godlovitch, R. and Harris, J. (eds.), Animals, Men and Morals. Victor Gollanz: London, 1971, 41-82.

SAVING WILDCATS. On the brink. https://savingwildcats.org.uk/. Accessed 13 April 2021.

SINGER, Peter. Animal Liberation: The Definitive Classic of the Animal Movement [Fortieth Anniversary Edition], Open Road: New York, 2015/1975.

SOLLUND, Ragnhild. Wildlife management, species injustice and ecocide in the Anthropocene. Critical Criminology, 2020, 28(3), 351-369.

The crimes of wildlife trafficking: issues of justice, legality and morality. Routledge: Abingdon, UK, 2019.

The animal other: legal and illegal theriocide. In Hall, M., Maher, J., Nurse, A., Potter, G., South, N. and Wyatt, T. (eds.). Greening Criminology in the 21st Century: Contemporary debates and future directions in the study of environmental harm. Routledge: London, 2017a, 79-99.

Perceptions and law enforcement of illegal and legal wolf killing in Norway: organized crime or folk crime?. Palgrave Communications. 2017b, 3(1), 1-9. 
Animal abuse, animal rights and species justice. In: American Society of Criminology 69th Annual Meeting, Atlanta. Animal Abuse, Animal Rights and Species Justice. 2013, 1-35.

Expressions of speciesism: the effects of keeping companion animals on animal abuse, animal trafficking and species decline. Crime, Law and Social Change. 2011, 55(5), 437-451.

WHITE, Rob. Environmental harm: An eco-justice perspective. Polity Press: Bristol, UK, 2013.

$\begin{array}{lllll}\text { WILDLIFE } & \text { AND } & \text { COUNTRYSIDE } & \text { ACT } & 1981 .\end{array}$ https://www.legislation.gov.uk/ukpga/1981/69. Accessed 8 April 2021.

WYATT, Tanya. Is CITES Protecting Wildlife? Assessing implementation and compliance. Earthscan: London, 2021a.

Wildlife trafficking: the deconstruction of the crime, the victims, and the offenders. Second edition. Palgrave Macmillan: London, 2021b.

The uncharismatic and unorganised side to wildlife smuggling. In Elliott, L. and Schaedla, W. (eds). Handbook of Transnational Environmental Crime. Edward Elgar: Cheltenham, 2016, 129-145. 